\title{
Zebrafish embryos as an alternative model for screening of drug-induced organ toxicity
}

\author{
S. Scholz
}

Received: 5 March 2013/ Accepted: 19 March 2013/Published online: 30 March 2013

(C) Springer-Verlag Berlin Heidelberg 2013

Zebrafish have initially emerged as model in developmental biology. The ease of maintenance, high number of offspring, transparency of the eggs and its suitability in mutagenicity screens to unravel developmental pathways contributed to its popularity. Today, it can be considered as one of the best characterised vertebrate models and more than 1,000 labs worldwide use the zebrafish (Strähle et al. 2012). At around 1990 zebrafish were discovered also as a toxicology model (Gorge and Nagel 1990), and the popularity is still increasing (Busch et al. 2011). A major reason for the attractiveness of this small teleost is associated with the suitability of its embryonic life stages. Early life stages are considered to sentinel no or less pain or discomfort when exposed to chemicals. Hence, according to European regulation (EU 2010), they are accepted as alternatives to animal experiments (Embry et al. 2010; Halder et al. 2010). Furthermore, the zebrafish embryo model has the principal capacity of high-throughput analysis and can be used in, for example, screenings for low toxicity of drug candidates.

Zebrafish embryos provide an enormous versatility of applications in both environmental and human hazard assessment ranging from acute systemic toxicity (Ali et al. 2011; Lammer et al. 2009; Padilla et al. 2012), chronic toxicity (Volz et al. 2011), teratogenicity (Gustafson et al. 2012; Selderslaghs et al. 2009), neuractivity/neurotoxicity (Kokel et al. 2010; Selderslaghs et al. 2010), and endocrine disruption (Brion et al. 2012; Thienpont et al. 2011) to specific organ toxicities (Berghmans et al. 2008; Parng et al. 2002).

S. Scholz $(\varangle)$

Department of Bioanalytical Ecotoxicology, UFZ - Helmholtz

Centre for Environmental Research, Permoserstr. 15,

04318 Leipzig, Germany

e-mail: Stefan.Scholz@ufz.de
As outlined by the paper of Driessen et al. in this issue of Archives in toxicology, hepatotoxicity is one of the major concerns of organ toxicity in drug development. Identification of hepatoxicity as early as possible in the drug development pipeline would reduce the costs associated with development of new medicines. Traditional animal models are time and cost intensive and subject to ethical concerns. Genuine cell-based in vitro methods do not provide the complexity of animal models and may provide only limited predictivity. Therefore, the zebrafish embryo has been proposed also as a better model to identify organ toxicity. As shown by Driessen et al., zebrafish embryos can indeed be used to identify hepatotoxicity. However, it is important to translate the observations appropriately, since histopathological effects or individual gene responses may differ among vertebrates.

Identification of key events and conserved mechanisms can be supported by toxicogenomic analysis, and hence, it is not surprising that the number of studies in zebrafish embryos supported or accompanied by toxicogenomic analysis is increasing (e.g. Büttner et al. 2012; Hermsen et al. 2012; Pelayo et al. 2012; Schiller et al. 2012; Yang et al. 2007). Transcriptional profiling of whole embryos is even able to reveal organ-specific profiles-as shown in the Driessen paper in this issue and by various other studies (e.g. Klüver et al. 2011; Yang et al. 2007). With the advent of next generation sequencing (NGS), new perspectives for transcriptome profiling by RNA-sequencing (RNA-seq) are provided also for the zebrafish embryo model (Aanes et al. 2011; Vesterlund et al. 2011). With RNA-seq, novel transcripts from annotated or non-annotated regions not available in predefined probe sets, alternative splicing forms and rare transcripts can be detected. This could be important for the comparative analysis and identification of conserved key toxicity pathways in vertebrates. At present, 
the technology of RNA-seq is still rather expensive but as has been shown by the Driessen paper, pooling of samples is possible and can partially overcome the limitation. In the future, the use of barcode technology may allow to analyse multiple samples in parallel, providing another way to reduce cost. RNA-seq may also be applied for a genuine organ-specific analysis in zebrafish embryos, by using transgenic strains, in which specific organs are labelled by the expression of a reporter gene or protein, respectively. Cell dissociation protocols are available and fluorescenceactivated cell sorting would allow restriction of toxicogenomic analysis to specific cell types in early life stages (Cui et al. 2011). A potential drawback of RNA-seq is that important signals detected by microarrays may not be sufficiently read due to coverage limitations. Thus, although RNA-seq holds good promises for routine use, it may at present not fully replace microarrays but provide complementary data.

A major issue of future research particularly for the extrapolations from zebrafish embryos to humans is also how the effect concentrations in embryos can be related to appropriate effect levels in mammalian models. Pharmacokinetics in genuine in vitro as well as in fish embryo models differ fundamentally from mammalian models (Noorlander et al. 2008). In the latter, drugs are often administered by single or repeated (oral) doses leading to specific time courses of plasma concentrations depending on the adsorption, distribution, metabolisation and excretion rates of the drug. In fish embryos, exposure is static and internal concentrations are established by partition equilibrium. Physiologically based kinetic models could provide a link between fish embryo and mammalian toxicity, but such models have not been developed for the fish embryo so far (Louisse et al. 2010). Furthermore, support by chemical analytics for the time-course of internal concentration in fish embryos would be needed. An alternative approach that may rely less on pharmacokinetic modelling could be the comparison of concentration-response curves for drug targets (therapeutic targets) with the appropriate curves for adverse effects such as hepatotoxicity. Clearly separated effect concentrations could identify promising compounds in drug screening approaches. This requires, however, also an appropriate concentration-response analysis that is lacking in most of zebrafish embryo studies with molecular endpoints or toxicogenomic analysis (Gündel et al. 2012). With the further development of technologies for transcriptional profiling, this can be expected to be facilitated.

The study of Driessen et al. has provided pioneering data for the use of zebrafish embryos as a hepatotoxic model and is the first study that compares embryonic and adult stages of fish with mouse and in vitro cellular models. The study provides promising evidence that the zebrafish embryo could be developed as a model to predict hepatoxicity for humans.

\section{References}

Aanes H, Winata CL, Lin CH, Chen JP, Srinivasan KG, Lee SGP, Lim AYM, Hajan HS, Collas P, Bourque G, Gong Z, Korzh V, Aleström P, Mathavan S (2011). Zebrafish mRNA sequencing deciphers novelties in transcriptome dynamics during maternal to zygotic transition. Genome Res 21:1328-1338. doi:10.1101/ gr.116012.110

Ali S, Mil HGJv, Richardson MK (2011) Large-scale assessment of the zebrafish embryo as a possible predictive model in toxicity testing. PLoS ONE 6:e21076

Berghmans S, Butler P, Goldsmith P, Waldron G, Gardner I, Golder Z, Richards FM, Kimber G, Roach A, Alderton W, Fleming A (2008) Zebrafish based assays for the assessment of cardiac, visual and gut function-potential safety screens for early drug discovery. J Pharmacol Toxicol Methods 58:59-68

Brion F, Le Page Y, Piccini B, Cardoso O, Tong S-K, Chung B-c, Kah O (2012) Screening estrogenic activities of chemicals or mixtures in vivo using transgenic (cyp19a1b-GFP) zebrafish embryos. PlosOne 7:e36069

Busch W, Duis K, Fenske M, Maack G, Legler J, Padilla S, Strähle U, Witters H, Scholz S (2011) The zebrafish embryo model in toxicology and teratology, September 2-3, 2010, Karlsruhe, Germany. Reprod Toxicol 31:585-588

Büttner A, Busch W, Klüver N, Giannis A, Scholz S (2012) Transcriptional responses of zebrafish embryos exposed to potential sonic hedgehog pathway interfering compounds deviate from expression profiles of cyclopamine. Reprod Toxicol $33: 254-263$

Cui C, Benard EL, Kanwal Z, Stockhammer OW, van der Vaart M, Zakrzewska A, Spaink HP, Meijer AH (2011) Infectious disease modelling and innate immune function in zebrafish embryos. Methods Cell Biol 105:273-308

Driessen M, Kienhuis AS, Pennings JLA, Pronk TE, van den Brandhof EJ, Roodbergen M, Spaink HP, van de Water B, van der Ven LTM (2013). Exploring the zebrafish embryo as an alternative model for the evaluation of liver toxicity by histopathology and expression profiling. Arch Toxicol (this issue)

Embry MR, Belanger SE, Braunbeck TA, Galay-Burgos M, Halder M, Hinton DE, Léonard MA, Lillicrap A, Norberg-King T, Whale G (2010) The fish embryo toxicity test as an animal alternative method in hazard and risk assessment and scientific research. Aquat Toxicol 97:79-87

EU (2010) Directive 2010/63/EU of the European parliament and of the council of 22 September 2010 on the protection of animals used for scientific purposes. OJ Eur Comm L 276:34-79

Gorge G, Nagel R (1990) Toxicity of lindane, atrazine, and deltamethrin to early life stages of zebrafish (Brachydanio rerio). Ecotoxicol Environ Saf 20:246-255

Gündel U, Kalkhof S, Zitzkat D, von Bergen M, Altenburger R, Küster E (2012) Concentration-response concept in ecotoxicoproteomics: effects of different phenanthrene concentrations to the zebrafish (Danio rerio) embryo proteome. Ecotoxicol Environ Saf 76:11-22

Gustafson AL, Stedman DB, Ball J, Hillegass JM, Flood A, Zhang CX, Panzica-Kelly J, Cao J, Coburn A, Enright BP, Tornesi MB, Hetheridge M, Augustine-Rauch KA (2012) Inter-laboratory assessment of a harmonized zebrafish developmental toxicology assay-progress report on phase I. Reprod Toxicol 33:155-164 
Halder M, Léonard M, Iguchi T, Oris JT, Ryder K, Belanger SE, Braunbeck TA, Embry MR, Whale G, Norberg-King T, Lillicrap A (2010) Regulatory aspects on the use of fish embryos in environmental toxicology. Integr Environ Assess Manag 6:484491

Hermsen SAB, Pronk TE, van den Brandhof E-J, van der Ven LTM, Piersma AH (2012) Concentration-response analysis of differential gene expression in the zebrafish embryotoxicity test following flusilazole exposure. Tox Sci 127:303-312

Klüver N, Yang L, Busch W, Scheffler K, Renner P, Strähle U, Scholz $S$ (2011). Transcriptional response of zebrafish embryos exposed to neurotoxic compounds reveals a muscle activity dependent hspb11 expression. PLoS ONE. doi:10.1371/journal.pone. 0029063

Kokel D, Bryan J, Laggner C, White R, Cheung CYJ, Mateus R, Healey D, Kim S, Werdich AA, Haggarty SJ, MacRae CA, Shoichet B, Peterson RT (2010) Rapid behavior-based identification of neuroactive small molecules in the zebrafish. Nat Chem Biol 6:231-237

Lammer E, Carr GJ, Wendler K, Rawlings JM, Belanger SE, Braunbeck T (2009) Is the fish embryo toxicity test (FET) with the zebrafish (Danio rerio) a potential alternative for the fish acute toxicity test? Comp Biochem Phys C 149:196-209

Louisse J, de Jong E, van de Sandt JJM, Blaauboer BJ, Woutersen RA, Piersma AH, Rietjens IMCM, Verwei M (2010) The use of in vitro toxicity data and physiologically based kinetic modeling to predict dose-response curves for in vivo developmental toxicity of glycol ethers in rat and man. Tox Sci 118:470-484

Noorlander C, Zeilmaker M, Eijkeren Jv, Bourgeois F, Beffers R, Brandon E, Bessems J (2008). Data collection on kinetic parameters of substances. Pilot phase-a methodological report-December 2008 CCR.IHCP.C432921.XO. Available at http://ecvam.jrc.it

Padilla S, Corum D, Padnos B, Hunter DL, Beam A, Houck KA, Sipes N, Kleinstreuer N, Knudsen T, Dix DJ, David RM (2012) Zebrafish developmental screening of the ToxCast(TM) phase 1 chemical library. Reprod Toxicol 33:174-187

Parng C, Seng WL, Semino C, McGrath P (2002) Zebrafish: a preclinical model for drug screening. Assay Drug Dev Technol $1: 41-48$
Pelayo S, Oliveira E, Thienpont B, Babin PJ, Raldua D, Andre M, Pina B (2012) Triiodothyronine-induced changes in the zebrafish transcriptome during the eleutheroembryonic stage: implications for bisphenol A developmental toxicity. Aquat Toxicol 110: $114-122$

Schiller V, Wichmann A, Kriehuber R, Muth-Kohne E, Giesy JP, Hecker M, Fenske M (2012) Studying the effects of genistein on gene expression of fish embryos as an alternative testing approach for endocrine disruption. Comp Biochem Phys C 157:41-53

Selderslaghs IWT, Van Rompay AR, De Coen W, Witters HE (2009) Development of a screening assay to identify teratogenic and embryotoxic chemicals using the zebrafish embryo. Reprod Toxicol 28:308-320

Selderslaghs IWT, Hooyberghs J, De Coen W, Witters HE (2010) Locomotor activity in zebrafish embryos: a new method to assess developmental neurotoxicity. Neurotoxicol Teratol 32:460-471

Strähle U, Scholz S, Geisler R, Greiner P, Hollert H, Rastegar S, Schumacher A, Selderslaghs I, Weiss C, Witters H, Braunbeck T (2012) Zebrafish embryos as an alternative to animal experiments-a commentary on the definition of the onset of protected life stages in animal welfare regulations. Reprod Toxicol 33:128-132

Thienpont B, Tingaud-Sequeira A, Prats E, Barata C, Babin PJ, Raldua D (2011) Zebrafish eleutheroembryos provide a suitable vertebrate model for screening chemicals that impair thyroid hormone synthesis. Environ Sci Technol 45:7525-7532

Vesterlund L, Jiao H, Unneberg P, Hovatta O, Kere J (2011) The zebrafish transcriptome during early development. BMC Dev Biol 11:30

Volz DC, Belanger S, Embry M, Padilla S, Sanderson H, Schirmer K, Scholz S, Villeneuve D (2011) Adverse outcome pathways during early fish development: a conceptual framework for identification of chemical screening and prioritization strategies. Tox Sci 123:349-358

Yang L, Kemadjou JR, Zinsmeister C, Bauer M, Legradi J, Müller F, Pankratz M, Jäkel J, Strähle U (2007) Transcriptional profiling reveals barcode-like toxicogenomic responses in the zebrafish embryo. Genome Biol 8:R227 